\title{
Sanctuary Practices in Scandinavian Transnational Cities: The Case of Public Libraries
}

Anna Lundberg and Lisa Dahlquist

The self-archived postprint version of this journal article is available at Linköping University Institutional Repository (DiVA):

http:// urn.kb.se/ resolve?urn=urn:nbn:se:liu:diva-147521

N.B.: When citing this work, cite the original publication.

Lundberg, A., Dahlquist, L., (2018), Sanctuary Practices in Scandinavian Transnational Cities: The

Case of Public Libraries, J ournal of Human Rights Practice. https:/ doi.org/ 10.1093/jhuman/ huy009

Original publication available at:

https:// doi.org/ 10.1093/jhuman/ huy009

Copyright: Oxford University Press (OUP) (Policy E - Oxford Open Option D) http:// www.oxfordjournals.org// 


\title{
PEER REVIEW ARTICLE
}

\section{Sanctuary Practices in Scandinavian Transnational Cities: The Case of Public Libraries}

Anna Lundberg and Lisa Dahlquist

\author{
Please cite: Anna Lundberg, Lisa Dahlquist (2018); Sanctuary Practices \\ in Scandinavian Transnational Cities: The Case of Public \\ Libraries, Journal of Human Rights Practice, \\ huy009, https://doi.org/10.1093/jhuman/huy009
}

\begin{abstract}
The article explores sanctuary practices within public institutions by examining instances where public libraries in Denmark (Copenhagen), Norway (Oslo) and Sweden (Malmö) open up their services for persons who lack residence permits on state territory (so-called irregular migrants). Public libraries in this study are understood to be public spheres where the right to information and the freedom of expression are safeguarded. Such spheres, where rights are provided are primarily open to citizens or other people with authorised residence. Hence, when public libraries offer their services to irregular migrants, this is a demonstration of how public institutions representing the sovereign may engage in contestations of deportation regimes produced by the sovereign. Such 'enactments of sanctuary', we argue, open up new meanings of Arendt's notion of 'the right to have rights'. Through an in-depth case study in Malmö, Sweden, the article suggests that a new role is emerging for local institutions as providers of 'transnational' rights decoupled from any territorial basis. Rather than being linked to nationhood, the institutional role in democracies may be constitutive of rights in the present context: the right to equal access to information and freedom of expression. An equally progressive development can be found in Norway; however, this is not the case in Denmark which could be understood as a reflection of Denmark's more restrictive approach to immigration in general.
\end{abstract}

Keywords: Acts of citizenship; regimes; library; local government; sanctuary; Scandinavian cities

\section{Introduction}

The city of Malmö in southern Sweden is a key site to understanding contemporary migration and rights practices as a contestation of governments' management of migration. Situated at the border to Denmark the city is sometimes referred to as the gateway to Sweden, and it is the largest arrival municipality for asylum seekers in Scandinavia. In 2013, an initiative of sanctuary was taken by the Malmö Cultural Committee which allowed rejected asylum seekers with an expulsion order, so called irregular migrants, to have access to all library services. The city's head librarian commented on the new policy that it is important for the library to be able to provide free and equal access to information and library services. It is, the librarian argued, important 'especially to the most vulnerable ... Free and equal access is 
the goal and mission of the public library' (Lovén 2013, authors' translation and emphasis). We will elaborate on this case further below as an illustration of local initiatives of rights claiming through sanctuary.

This article contributes to discussions about the role of libraries and other public institutions in a transnational world where migration takes place in new and unconventional ways. This is also a world where a growing number of people have multiple ties across state borders (Povrzanovic Frykman 2004; Rastas 2013), and where refugees reside for longer periods of time as irregularized, that is, as persons who lack formal residence permits and thus are ‘deportable’ De Genova 2002). Drawing on the argument by Julie Biando Edwards (2010: 15), that public libraries, communities and human rights are not enough discussed together in the academic literature, the article investigates sanctuary initiatives in Scandinavian city libraries. These actions, which both safeguard access to rights and protect from police detection, demonstrate new ways of inventing a 'right to have rights' (Arendt 1951: Chapter 9) and alternative forms of citizenship (Isin and Nielsen 2008; Nordling 2017).

More specifically, the present study investigates how inventions of rights, on behalf of irregular migrants, may emerge within the confines of the sovereign, and yet, in contestation of the state's deportation regime. Furthermore, our case study relates to discussions about how cities may expand the meaning of human rights (Soohoo 2016: 258; Oomen 2016) including the role of administrative courts, in times of increasingly restrictive migration control measures.

In these contexts, the present article aims to explore sanctuary initiatives of Scandinavian city libraries, and point to their broader implications for the invention and re-invention of rights. In addition to highlighting how enactments of rights materialize within city libraries as public spheres, a broader ambition of our research is to engage in the political discussion about rights in times of increasingly violent migration management. The issue of irregular residents' access to library services raises questions about transnationality and visibility, as well as the role of public spheres and human rights in the city. Our case serves as an illustration of micro-level contestations in an era where representatives of the political establishment increasingly refer to the need for exclusionary practices that will prevent refugees from entering Europe (see Peutz and de Genova 2010; see also Rajaram and Grundy-Warr 2004: 41; Watters 2008).

Our main case for the present article is the city library in Malmö, Sweden, with Copenhagen, the capital of Denmark, and Oslo, the capital city of Norway, as comparative reference points for our analysis. All three sites are renowned as having a strong welfare system, a regulated labour market and 'liberal values' - that is, typical Scandinavian values. However, they also show important variances. One difference concerns the asylum reception system where Denmark, aiming at lowering the number of asylum applications, traditionally has shown stricter control procedures than the other countries. Both Norway and Sweden until recently have had a less control-oriented system, with greater opportunity for asylum seekers to get a work permit, and no specially designated accommodation where asylum seekers are required to stay (Jørgensen and Meret 2010: 131f). Furthermore, the governments in Sweden and 
Norway over the last decade have gradually extended social rights for irregular migrants, which has not been the case in Denmark.

Irregular migration in Scandinavia has not until recently been subject to much scholarly interest (Jørgensen and Meret 2012). Current studies have highlighted conditions of irregularity (Sager et al. 2016), suggesting that a historically strong welfare system combined with an extended bureaucracy have led to a production of irregularity that has had profound effects on marginalized groups in general (Lundberg and Strange 2016). A related area where the Scandinavian context is also under-researched is sanctuary, as in providing protection from deportation. An exception is a comparative study by Jill Loga, Miikka Pyykkönen and Hanne Stenvaag (2013), which points to the close relationship between state and church in the Nordic countries. This relationship constitutes a paradox of more effective protection of persons seeking sanctuary together with a connection where actors such as the church do not want to offend the state. The authors conclude that the most stable sanctuary is found in Swedish monasteries-i.e. Alsike monastery located in the countryside near Uppsala—and yet that in Sweden and Denmark 'it is clearly more risky to take sanctuary' (Loga et al. 2014: 132) than in Norway and Finland. Martin Bak Jørgensen and Susi Meret (2012) make a similar observation in their comparative study of Scandinavian debates around irregular migration. In Denmark, they state, 'the solution to irregular migration is mainly based on stricter and more effective control-mechanisms and return policies’ (Jørgensen and Meret 2012: 295).

Before further presenting the Malmö initiative of sanctuary, the next section continues with our methodological considerations, followed by a section about previous research on sanctuary enactments in relation to the notion of 'acts of citizenship' and rights in the city. The notion of public spheres is brought up in relation to the role of libraries in transnational cities. Then, as an introduction to our case, we present key similarities and differences between the Scandinavian legislative frameworks as regards the role and mission of libraries. This is followed by a presentation of our empirical findings through the Malmö case, as well as Copenhagen and Oslo where we conducted an email survey. Lastly, the emergence of contestations of state-centred migration control regimes within public local institutions is discussed as a practice of human rights as well as an illustration of new forms of citizenship in contemporary cities that are influenced by human mobility.

\section{Research design and methods}

The broader issue of rights claiming by or on behalf of irregular migrants in the present study was investigated from 2014 to 2016 within the framework of a research project about human rights and irregular migration, including ethnographic fieldwork and a policy study in Malmö, Sweden and Birmingham, UK (Lundberg and Strange 2016, 2017). ${ }^{1}$ For the present article, the first author conducted an email survey with librarians working in the city libraries in Copenhagen (Denmark), Malmö (Sweden) and Oslo (Norway). The second

\footnotetext{
${ }^{1}$ The project, financed by the Swedish Research Council (421-2012-683), takes an activist approach in that the scholars involved also support initiatives by irregularized residents. For activities and publications, see https://blogg.mah.se/undocumentedmigrants.
} 
author investigated national legislation framing the mission of libraries in Scandinavia and conducted ethnographic fieldwork in three different Swedish public libraries as part of her $\mathrm{PhD}$ project which focused on the public library's educational and democratic role in a digital and socially sustainable society.

Whereas the study of legislation aimed to demonstrate a formal context for rights provision in city libraries, the purpose of the survey was to find out how libraries frame these rights in policy and practice, and to get an insight into the related discussions and practices among the library staff. Questions were asked about relevant regulation and policy guidelines related to irregularized persons' access to library services: whether persons categorized as irregularized did use library services and how this was facilitated.

Informants were approached through the network of librarians in Malmö including their acquaintances among members of the Scandinavian National Library Associations. To begin with, we sent the survey to ten individual librarians. All were asked to distribute the questions in their networks to find the relevant persons. All informants came back to us with answers or forwarded our questions to someone who had relevant knowledge. Ten individual librarians answered the survey. Through follow-up conversations over email respondents expanded upon the answers given in the surveys. This was particularly useful in the case of Copenhagen since the answers we acquired varied and demonstrated the room for discretion available to the local libraries. We eventually got a close insight into the general problem of practising rights through sanctuary initiatives in a public sphere, in times of increasingly restrictive migration control.

In our analysis of the legislation and the survey answers, the focus was on the right of irregular migrants to make use of library services, as well as on what negotiations irregular migration led to in the everyday practice of the libraries. We were interested in the arguments both for and against equal access to library services, and how the issue of protection from detection by the border police was handled. The implications of negotiations around these issues is of concern for the broader understanding of rights in a transnational world in general and rights in a city context in particular.

Apart from the survey and legislation, empirical material came from a decision by the administrative court regarding the right of irregularized city inhabitants in Malmö to use public library services. Our analysis should be viewed in light of a deeper contextual understanding of the situation in Malmö, including the media debate that surrounded Malmö Public Library’s decision. The authors' ethnographic fieldwork was important for a contextual understanding of the situation in Swedish libraries at the time of the decision. During our fieldwork, we found several reasons for the importance of the library as a place to visit outside home for someone who is residing without authorization: to access different kinds of information, for knowledge development, or to deal with practical matters such as faxing or emailing public authorities. This was particularly noticeable during the fall of 2015 when a large number of refugees from Syria applied for asylum at the Migration Agency in Malmö, and proposals were repeatedly made and put forward for more restrictions on the rights of people who had had their application for asylum in Sweden rejected (Crouch 2015). 
In 2016-2017 the search for irregular migrants has been heightened and the debate has intensified, as the police turned to the social services for irregular migrants' residential addresses. ${ }^{2}$ It is in the light of these highly topical debates that the present study was conducted.

\section{Previous research}

Sanctuary initiatives as a contestation of the deportation regime

A common denominator in research about irregular migration is the strong focus on the sovereign, as in the state making decisions about migration control (Schmitt 1985; Watters 2008; Thomsen et al. 2010). Nicholas De Genova and Nathalie Peutz (2010) use the term 'deportation' in this context as an indisputable recourse of the administration that verifies and reaffirms state sovereignty. Deportation, they argue, is simultaneously a unified and global response to a world that is changing through transnational mobility. Moreover, it is an expression of trends endangering 'dominant notions of sovereignty, citizenship, public health, national identity, cultural homogeneity, racial purity, and class privilege' (Peutz and de Genova 2010: 2).

Contestations of the deportation regime, for example in practices of sanctuary (see Lippert and Rehaag 2013) have been explored through the so-called new sanctuary movement (Stoltz Chinchilla et al. 2009; Yukich 2013a, 2013b), various ground-up initiatives as well as in political theory (Squire 2010). Caroline Patsias and Nastassia Williams (2013: 176) argue that assisting migrants who reside without authorization is not a violation of law but rather a political obligation. Hilary Cunningham (2013) makes a similar point in her understanding of sanctuary as a practice upholding the law in the face of unlawful state actions; sanctuary initiatives are, she claims, 'civil initiatives'. The underlying basis of these arguments is that the state's migration control measures are currently so aberrant that it is the state that breaks the law.

Previous studies relating to sanctuary and inclusion have also emphasized local initiatives where refugees and asylum seekers themselves have taken an active role. Such involvement has been explored as the reinvention of cities through taking part in demonstrations and social movements (Darling 2016), acts of citizenship as refugee rights activists (Nyers 2008), practices of inclusion through 'radical accompaniment' (Yukich 2013b), or refugees' negotiations to become 'proactive social actors' through transnational networks (Williams 2006). Moreover, sanctuary has been explored as an example of claims to 'rightful presence', 'networks of solidarity', and claims for justice as an account of the 'urbanization of human rights’ (Darling 2016: 123; see also Darling and Squire 2013). Considering the strong position of the sovereign state as both 'human rights-implementer' and 'migrationcontroller' - in other words, the actor with legitimate power to determine who can be included and who should be expelled-practices of contestation within the sphere of the sovereign are interesting. Such initiatives may constitute the emergence of new forms of

\footnotetext{
${ }^{2}$ Since 2013 irregular migrant families with children below the age of 18 in Malmö have a right to the same economic support from the social services as permanent residents. A condition for support is that the family concerned provide a residential address (see Justitieombudsmannen 2017).
} 
rights enactments and urban forms of citizenship which challenge the deportation regime in the name of equality.

An example of city-based sanctuary practices occurred in San Francisco, with the adoption of legislation that required municipal employees to cease all participation in immigration policing and provide services to all city residents irrespective of their immigration status. This was the result of a 'municipal regulatory regime' created by a 'wide variety of governmental actors' which were 'watched over by immigrant community organizations with the purpose of regulating city employee practices' (Mancina 2016: 5). Municipal departments and agencies in the city were increasingly engaged with various sanctuary movement organizations, which in turn provided technical assistance to city agencies in how to handle the risk of deportation (ibid: Chapter 2). Key factors in the process of developing a long-term governmental response and sustainable sanctuary were mixed legal advocacy and community education combined with campaigning for the right to political asylum by a network of civil society groups. In addition, there was a focus aimed at changing the routine work of the police. Peter Mancina (2016) argues that an important aspect of the San Francisco case was that it moved beyond the struggle for refugees' rights and came to provide a point of focus for political work: work with the goal of having a city where all residents could release themselves from any discriminatory treatment from the authorities. Hence, sanctuary practices were used as 'morally imbued techniques for city management, maintenance of public order, and promotion of the general welfare’ (ibid: 57).

\section{Acts of citizenship and claims for rights in 'human rights cities'}

An important entry point for the present study is rights claiming through sanctuary initiatives as a form of local human rights practice in the city. Human rights cities are an emerging theme and a driving force of human rights practices (Oomen et al. 2016). In this development an important element is multi-actor governance rather than purely state-led government. Two related notions when exploring sanctuary initiatives in the city are acts of citizenship and rights claims to encounter exclusions and inequalities. Citizenship in general is a site of political struggles (Osler and Starkey 2005: 9) and this is even more so through the notion of 'acts of citizenship' (Isin and Nielsen 2008; Nordling 2017). This refers to acts when subjects, regardless of citizenship status, constitute themselves as if they were citizens, and the notion is thus an alternative approach to citizenship as a formal status. ${ }^{3}$ Through everyday deeds, 'ordinarily called politics’ (Isin and Nielsen 2008: 2), a broadened understanding of

\footnotetext{
${ }^{3}$ Citizenship is a contentious concept that is not easily defined. Citizenship is typically understood in relation to legal status, but can also be analysed from a wider, social sense. The latter perspective is often emphasized from a critical understanding of citizenship (Lister 2007; 2010). From such a perspective, citizenship can be referred to as a momentum concept which means that it is constantly revised so that it honours more of its egalitarian and non-hierarchical potential (Hoffman 2004). This means that it is also possible to discuss the more informal ways to citizenship, acknowledging that the concept of citizenship also involves social, political and cultural practices.
} 
citizenship is introduced, which stresses collective or individual actions that break up, disrupt and transform social-historical patterns (ibid: 2). Ground-up rights claims are central to grasp these deeds with their overlapping and interdependent components. From such a perspective, the public library_-by opening up their services for persons who lack residence permits on state territory — can be seen as a public institution which both takes part in, and enables, acts of citizenship by providing a public space, free and open for all-in other words, providing a public sphere for active citizenship and civic engagement.

Rights practices through sanctuary within libraries have not been discussed in previous research at all, as far as we have been able to assess (cf. Biando Edwards 2010; Martinez 2013). Our study wants to contribute to an understanding of how sanctuary practices as rights-claiming and a contestation of deportation regimes can manifest themselves within local governments providing public services, such as the public library, and through these processes make visible alternative forms of citizenship. Besides providing equal access to information, libraries also play a social role as a community meeting-place, a 'third place' (Oldenburg 1999) or 'an equalizer' in a broader sense (Audunson 2005; Aabø et al. 2010; Audunson et al. 2011). They are open public spheres (Buschman 2003; Buschman and Leckie 2007: 15) which, as we will demonstrate, have a specific role in the dynamic politics of contestations of the sovereign's deportation regime.

Ruth Fincher and Kurt Iveson discuss public libraries as elements of urban infrastructures, which implies that these institutions, with their services, have a particular role in making new social relationships possible (Dudley 2013: 16f). In other words, libraries are public places that are free and open to all inhabitants in a city, and hence activities in libraries are closely connected to the democratic process and community building. As noted by Jennifer Hoyer (2013: 60), 'libraries take a key role in helping everyone become active members of society and in creating healthy, equitable communities'. From this point of view, a central role of libraries is to stimulate the development of cultural diversity and, in the long term, to play a role in relation to the development of 'multi-ethnic society' (Hvenegaard Rasmussen and Jochumesen 2007). This way public libraries may be conceptualized in terms of open spheres for strengthened ground-up social cohesion.

These perspectives of city libraries as a site for claims-making and acts of citizenship relate to ideas about equality in local contexts. Graham and others (2016) argue, for example, that cities are at the forefront of new forms of human rights practice, 'moving away from singular, top down, state-focused strategies in favour of multi-dimensional, multi-actor, contextual and bottom-up, grassroots approaches' (Graham et al. 2016: 179). In this context, 'human rights cities' emerges as a new form of local governance connecting various actors and open to complex relationships, and rooted on 'meta-governance values, such as non-discrimination' (ibid: 183), yet still retaining the state as an important actor with a specific set of responsibilities. In relation to migration management, besides making claims for services on behalf of those who are under threat of deportation, the issue of protection from the deportation regime bound up with access to social services.

To conclude, public libraries have the potential to serve as protected transboundary meetingplaces for people regardless of their legal status, and as open spheres for rights claiming. To 
do so they need to take shape in co-agency with the surrounding society and consider contextual factors such as irregular migration in the contemporary world and deportation as a state practice. In this context the public library needs to be a protected and simultaneously an open plural sphere. Local achievements in the long term can also have implications for broader social perspectives on inclusion.

In the following section, sanctuary as a right to take part in public libraries' services will be explored through the case of Malmö. We begin with a brief presentation of the institutional characteristics of public libraries in Scandinavia, including legislative frameworks bringing together human rights and library services.

\section{Scandinavian libraries' role as rights provider in transnational cities}

While the implementation of human rights treaties has its basis in public international law (that is, formal agreements between states parties), public libraries as well as schools, universities and museums have a historically close relationship with the notion of the public sphere that rests on the idea of a place that is free and open to all. It is a place where inhabitants can share opinions, take part in public discussion and access information. Public libraries as public institutions hence both provide information as a pathway to the implementation of human rights treaties and serve as a sphere where people can meet and take part in discussions and educational activities. This was discussed above in terms of public libraries as being essential in democratic societies.

Internationally, fundamental principles of public libraries are laid out in UNESCO's 'Public Library Manifesto'. It is worth noting that this does not mention the legal status of users. It was elaborated in collaboration between UNESCO and the International Federation of Library Associations and Institutions (IFLA), ${ }^{4}$ and was first adopted in 1949. Today's revised version was adopted in 1994 and it plays a key role in discussions about the role of libraries in a globalized world (Laugesen 2014). According to the manifesto, one fundamental role of the public library is to 'foster well-informed' inhabitants to play an active role in democratic societies and to provide equal services for all: 'Services of the public library are provided on the basis of equality of access for all, regardless of age, race, sex, religion, nationality, language or social status' (UNESCO 1994). This demonstrates a clear connection between the public libraries' obligation to provide access to information without distinction and the articles in the Universal Declaration of Human Rights (see Article 19) as well as the International Covenant on Civil and Political Rights (see Article 19) stipulating the right to information and freedom of expression.

On the state level, national laws regulate public library institutions in all the Scandinavian countries. In Sweden, the Library Act (SFS 2013: 801) is a so-called frame law, which means that it states general principles and guidelines for publicly funded library institutions. It is stated in the Act that the main purpose of public library institutions is to act upon the democratic development of society by promoting the dissemination of knowledge and freedom of opinion (para. 2). The Act further obliges municipalities to provide access to

\footnotetext{
${ }^{4}$ IFLA is the leading international body representing the interests of library and information services and their users. It is the global voice of the library and information profession (IFLA 2016).
} 
library services, but it does not entitle individual persons to claim a certain right to these (Proposition 2012/13:147: 7-8). Recently the Swedish Library Act was revised in a direction of importance to the current study, namely through the replacement of the term 'citizen' with 'all'. Furthermore, in the revised legislation, national minority groups as well as people with another mother tongue than Swedish are declared to be priority groups (Swedish Library Act 2013, para. 5).

According to the Danish Library Act (Lov om biblioteksverksamhet 2000), the main objective of public libraries is to promote information, education and cultural activity (§ 1). There is no account of whom the services should be directed to. In the Norwegian Public Library Act (Lov-2013-06-21-95), a similar formulation states that the goal of public libraries is 'to promote information, education and other cultural activity ... for free to everyone inhabiting the country' ( $\S 1$, authors' translation). Further, it is stated that public libraries should provide an arena for public discussion and debate (\$1, authors' translation). While the legislation on public libraries in Norway states that services should be free of charge for everyone, this free service does not necessarily mean that everyone can get a library card, and thus there is room for discretion in local government when deciding who should get a library card (Department manager at Deichmanske Bibliotek, Lambertseter filial, email message to the author, 24 March 2015). Hence, the Swedish Library Act is the only one of the three pieces of Scandinavian legislation which explicitly declares that libraries should act for the democratic development of society and provide services for all. The recent change of wording in the Act is an official step towards providing rights on behalf of all people, regardless of their legal status.

How these legislative frameworks relate to sanctuary enactments in practice will be our focus below through the empirical case of Malmö City's decision to open up access to all library services for irregular migrants.

\section{Enactments of rights through local sanctuary practices}

\section{The Malmö case}

In June 2013, the Cultural Committee in Malmö adopted a decision to allow persons who are residing in Sweden without formal authorization to be guaranteed access the city library. Also, persons who lack identity documents were subject to the decision. Concretely, the agreement stated that persons who reside as irregularized in Malmö were entitled to enter into a special, time-limited agreement and obtain a library card with six months' validity. To not expose irregularized persons to any danger of being searched by the police, a special procedure of registration was adopted that differed from the ordinary procedure where the patron's address is registered. More specifically, in operationalizing the Cultural Committee's decision, Malmö City Library developed a written agreement for obtaining a library card to be signed by both the librarian and the patron. In this agreement, the library's address, instead of the patron's, is notified, together with the name and email address of the patron.

Many residents of Malmö, especially the asylum rights movement, were in favour of the new policy, but some were also reluctant and others even engaged in protests. One Malmö 
resident handed in a formal appeal to the Administrative Court, claiming that the decision was unfair to the municipality's citizens. 'The library would supply books to the destitute despite the likelihood that they will not be returned', he stated in the appeal. Moreover, he argued that the decision was contrary to the principle of equality of city inhabitants since everyone else must notify their address when registering a library card. The Cultural Council in Malmö disputed the appeal, stating that the assignment of the library had been decided to provide, as far as possible, the same services for irregular migrants as they do with regard to other city inhabitants. The city then described the reasons for their decision:

The decision means that irregular migrants residing in Malmö shall be able to enter into a special, time-limited, agreement and get a library card valid for six months. By offering irregular migrants the same terms and conditions as other patrons the municipality of Malmö follows the library law and the public libraries' mission. The principle of equality in municipal law [as in equal treatment] applies only to the municipality's permanent inhabitants (authors' translation and emphasis).

The Court in their judgment did not value these arguments but they nevertheless dismissed the appeal. To start off, the court stated, as an administrative court they could only review whether the library's decision was adopted in a formally correct manner according to municipal law. Accordingly, the court could only speak about the legality of the decision and not its rightness. Hence, the court did not give any justification for the library's decision. Furthermore, the administrative court only had a mandate to decide on whether the decision was to be cancelled or not. They concluded that a different treatment actually is indeed ivalid for irregular migrants, and therefore the decision was in accordance with the law. The court based this conclusion on the fact that 'undocumented migrants' is a group of residents for which 'there is no legal definition in Sweden'. Also, they are not formally counted as 'members of Malmö municipality' and thus nor are they covered by the principle of equality in the Local Government Act (SFS 1991:900, see Chapter 2 section 2). The equality principle states that the court of appeal only applies to the municipality's authorized residents. Since there is no legal definition of 'undocumented migrants', nor does the group exist formally, the court reasoned, irregular migrants cannot be considered to be local residents (Administrative Court of Malmö, decision 61-4213). Consequently, to permit persons residing irregularly access to library services, and whether to treat them differently to protect them from deportation, was outside the court's jurisdiction. The public debate following this decision, however, turned out to revolve around that matter.

The librarians responsible commented on the court case in newspaper interviews, stating that it is important for Malmö City Library to be able to provide free and equal access to information and experiences for all: 'We see the library as a sanctuary, and we are here for everyone. Therefore, each and every one must have the opportunity to borrow books' (Lovén 2013, authors' translation and emphasis). In another interview one of the librarians declared:

Carelessness and fraud, but above all, the fact that irregular migrants live under the constant threat of detention and forced deportation, could perhaps lead to some loss. This is a risk we must take and weigh against how much it is worth, especially 
for the most vulnerable populations to receive equal access to our content and services. But of course, we must closely monitor this so that it is not abused (Mikkelsen 2014, authors' translation and emphasis).

The librarian in the first quotation above argued that free and equal access to information and other services is a central goal and mission of the library. The second quotation demonstrates a contextual awareness in regard to the everyday struggles of irregular migrants.

While an important strategy and endeavour of sanctuary, in the sense of providing sanctuary from the deportation regime (Peutz and de Genova 2010), complete safety is not possible in public spheres. In Malmö, as in the whole of Sweden, there are no places where persons can securely hide from the police. Police officers' stop and search procedures are permitted throughout state territory (with some restrictions in health care settings). Consequently, the police, as a rule, may attend all public institutions in search of 'deportables', and at the time of writing, the search for persons who should be expelled has gradually intensified (Crouch 2016; Lundberg and Strange 2016; see note 3). However, for the librarians in their contestations of the deportation regime, it was central to avoid putting irregular migrants at risk of being detected. In this way, they enacted human rights in a city context which is increasingly characterized by restrictive migration management.

\section{Sanctuary enactments in Stockholm}

As noted in the section on methodological considerations, we searched for examples of sanctuary initiatives in other Scandinavian cities through our contacts with librarians in Malmö and, in turn, their contacts within the National Library Associations in Scandinavia. Early in our work we noted that there are no general policies for public libraries in Scandinavia in relation to irregular migrants, and that the issue of irregularized persons accessing library services is sometimes a sensitive and difficult matter for the staff to handle. We found that later in 2013, the Cultural Committee of the Swedish capital of Stockholm decided to let persons without ID documents or without an address to obtain library cards. The same way as in Malmö, this was claimed to be a matter of rights as well as a matter of the libraries' mission. All city inhabitants, regardless of legal status, were to gain access to services and media provided by libraries. The background was that four politicians from different parties in the Culture Committee (a Social Democrat, a leftist-party member and two persons from the Green Party) proposed a system that enables the issuance of library cards to persons with no personal number. The politicians stressed that libraries are vital centres for democracy which were at present not accessible for all city residents:

To acquire a library card so that one can borrow books and access other services, it is required that one can state a permanent address. This excludes those who have had their asylum application rejected and are now living as 'irregularized' in the city. These people, who have the right to schooling and health care, should of course also be able to borrow books and use the services of the library (Fellbom Franke 2013: 46, authors' translation and emphasis).

In this quotation, a broader contextual understanding of inclusionary politics in the city-a form of rights practice - is brought forward as a basis for expanding rights for irregularized 
residents. In a wider perspective, these statements may be understood as part of a puzzle of institutional contestations of the state's deportation regime and a struggle over human rights in the city.

As in Malmö, the Stockholm library developed a procedure in which irregular migrants, when applying for a library card, were exempted from meeting the requirement of having a permanent address in Sweden and ID. This group has access to the same rights and obligations as 'ordinary borrowers'. Cancellation fees and reservation fees are charged as usual and the card is blocked if the fees exceed 100 Swedish crowns (email from Stockholm librarian 2017-05-12). The same way as in Malmö, the Stockholm arrangement fostered an idea of equal access while protecting against deportation, as two sides of the same coin.

\section{Sanctuary enactments in Copenhagen and Oslo}

Comparable initiatives to the Swedish examples above also appeared in the Norwegian capital, Oslo. Here, identification numbers as well as permanent address and full personal number (so called D- or DUF-number) are regularly required for persons to hold a library card. Consequently, and as openly expressed in one of the answers to our survey, 'unacceptably', neither irregular nor homeless persons were previously allowed to borrow books. The issue of irregularized users in Oslo, as one representative of the Norwegian National Library Association described the matter, led to 'extensive discussions among library personnel'. There were also claims made by irregular migrants themselves, and on their behalf by a Norwegian NGO 'the Oslo Battery', to make library resources more accessible. Eventually, a central agreement was adopted where 'the Oslo Battery' took responsibility for library cards that are used by people who do not have ID cards, DUF number or birth- and social security numbers (Oslo Battery 2016). In conclusion, some of the library staff mentioned in the survey that their colleagues had been afraid the library would lose books, while others stressed the role of the library to be open for all residents and consequently they ought to secure equal access to its services.

With regard to protection from detection and deportation special arrangements were necessary. To gain access library users must provide contact details through which the library can contact them. However, this does not have to be a postal address, an email address will also suffice. The reason for this open approach was explained in the following way by one respondent: 'the situation for these people is basically so miserable and sad, that we should reach far. And that we did.' With regard to some members of the staff who were afraid of losing books, the librarian stated, 'this was shown not to be the case'. Clearly, it was somewhat controversial in Norway, just like in Sweden, to provide access to library services to persons who were not authorized to reside in the country. Nonetheless, initiatives in recent years have led to better policies. Also, local ad hoc initiatives appeared to be important as a starting point for other libraries to initiate policy changes in the same direction.

While there is no central or overall practice when it comes to the issue of sanctuary in Sweden or Norway, it appears as though Denmark in general has a stronger policy of excluding persons who are in the asylum process or have had their application rejected. In Denmark, initiatives similar to those of Norway and Sweden were not found in our study. From the libraries' perspective, this is due to a general formal requirement to show a health 
insurance card, and this is awarded in connection with the granting of residence permits and civil registration. If a person does not have a health insurance card, a library card cannot be provided. Persons are not, as one respondent in Denmark expressed it, given a library card 'just by verbally saying who they are'. Exceptionally, according to one of our informants with whom we had repeated contact, asylum centres in Denmark have signed agreements with the local library, but in general, asylum seekers are excluded from libraries in Denmark. This means that it is impossible for persons in an irregularized situation to make use of library services on equal terms.

\section{Concluding analysis}

The case studies conducted for the present article demonstrate how rights practices and acts of citizenship may emerge in contemporary times of increasingly harsh measures by the state to deport irregular migrants. More specifically, we have investigated how inventions of rights through sanctuary materialize within the confines of public institutions, and yet, in contestation of the state's deportation regime. Whereas non-discrimination and the role of the institutions to provide equal access to services are constitutive of rights claims, in the case of 'deportees', special context-sensitive considerations are necessary in the implementation process of these rights. We have demonstrated that safeguarding equal access to rights is a struggle shaped by contextual factors such as transborder human mobility and state migration control which makes itself felt in the everyday life of city residents.

When exploring the emergence of new forms of a right to have rights and of citizenship, we investigated several parallel and intertwined developments. The struggle in Malmö and Stockholm, compared to the sites in Copenhagen and Oslo, illustrated firstly that an awareness of deportation regimes and their local implications is central for enactments of sanctuary. Secondly, alertness to the democratic role of public institutions and their mission appears to be constitutive for equal access to rights, in times of increasingly restrictive and violent migration management. Thirdly, the case of Malmö suggests that an important dimension of enactments of sanctuary, even though these imply some kind of secrecy, are public statements about the democratic role of open institutions. Fourthly, rights seem to magnify themselves - if one institution acts on behalf of irregular migrants, others see that this is possible and may follow. Fifthly, the perceived fear that a few librarians mentioned in our study, of losing books or making bureaucratic mistakes by failing to request identification documents or a residence address, although they proved unfounded, should still be considered — and elaborated through collective reflections - in micro-level sanctuary politics. Sixthly and finally, legislative frameworks specifying that public services are for all provide an important basis for rights claiming and acts of citizenship.

Visions about the role of open protected spheres for all city residents that we found in Malmö and Stockholm were also present in Oslo. In Denmark, however, which historically has had a harsher climate of debate in the field of migration, the law regarding the role of libraries and local rights practices on behalf of irregular migrants were more limited.

The focus on equality and the reinvention of rights that we identified differs from other arrangements of welfare services for irregular migrants. When the right to health care for irregular migrants was legislated in Sweden in 2013, it was done by singling out the group of 
'undocumented persons' in a special national law. Adult irregular migrants were entitled to a reduced health care, children, given their status as children, were entitled to equal access (see Lundberg and Strange 2017). When policies on the right to equal economic support for irregular families were adopted in the city of Malmö some years ago, it was a condition for help that each and every family concerned provided a residential address. A few years later, in the spring of 2017, when deportations became a high political priority in Sweden, the police requested the housing addresses from the social services. In the next step this led to the expulsion of several families. Through a simple request from the police, irregular families' social rights were undermined overnight. The example demonstrates the relation between ensuring rights for irregular migrants on one hand and a critical awareness of the possible actions by the state's migration management on the other hand. In other words, protection from the state was central for local rights, and it required special measures.

When public libraries in Swedish and Norwegian cities have opened up their services to irregularized persons and to protect these ‘deportables' from the state's migration management, they also do something else, namely protect the library as a public institution from being drawn into the deportation machinery. This suggests that public institutions when they stand out as guarantors of sanctuary-wherever it is enacted-also more or less consciously contradict a totalitarian social development. The Malmö case, at least, illustrates that access to rights for irregular migrants is more than a struggle over migration politics. It is also about the role of public institutions in a transnational world where states are presently adopting more restrictive migration control measures.

To conclude, our study demonstrates that rights claims may not be understood as completely decoupled from citizenship. Nor should rights struggles on a local level be pursued completely detached from decisions by the sovereign. A right to have rights, as Arendt noted, is dependent on inclusion in the political community of statehood. This is a fact also in the contemporary transnational world of human mobility, where the risk of deportation is often triggered when irregular migrants turn to public institutions. However, through local sanctuary initiatives, new alternative forms of citizenship and rights practices emerge, decoupled from the territorial basis of rights claims. When enacted inside established public institutions, the rights practices may be understood as claims made on the basis of the institution's mission and local role as service provider in the everyday life of residents. Such new forms of human rights practices, where access to rights and protection from the state are reflected as two sides of the same coin, need further exploration in human rights research. Here, synergies between international and local rights struggles, to embrace social assistance as rights rather than services, may be instructive (Alston 2017).

\section{Funding}

This work was generously supported by the Swedish Research Council under Grant number 421-2012-683.

\section{References}

Aabø, S., R. Audunson, and A. Vårheim. 2010. How do Public Libraries Function as Meeting Places? Library \& Information Science Research, 2(1): 16-26. 
Administrative Court of Malmö, Case 61-4213, Förvaltningsrätten i Malmö.

Alston, P. 2017. The Populist Challenge to Human Rights. Journal of Human Rights Practice 9(1): 1-15.

Arendt, H. 1951. The Origins of Totalitarianism. Houghton Mifflin Harcourt.

Audunson, R. 2005. The Public Library as a Meeting-Place in a Multicultural and Digital Context: The Necessity of Low-Intensive Meeting-Places. Journal of Documentation 61(3): 429-41.

Audunson, R., S. Essmat, and S. Aabø. 2011. Public Libraries: A Meeting Place for Immigrant Women? Library \& Information Science Research 33(3): 220-7.

Biando Edwards, J. 2010. Symbolic Possibilities. In J. Biando Edwards and S. P. Edwards, (eds), Beyond Article 19: Libraries and Social and Cultural Rights. Library Juice Press, LLC.

Buschman, J. 2003. Dismantling the Public Sphere: Situating and Sustaining Librarianship in the Age of the New Public Philosophy. Westport, CT: Libraries Unlimited.

Buschman, J., and G. J. Leckie. 2007. The Library as Place: History, Community, and Culture. Libraries Unlimited, Westport, Conn.

Crouch, D. 2015. Sweden Slams Shut its Open-Door Policy Towards Refugees. The Guardian. 24 November. https://www.theguardian.com/world/2015/nov/24/sweden-asylum-seekersrefugees-policy-reversal (referenced 8 September 2016).

Cunningham, H. 2013. From Humanitarian and Compassionate Review to Civil Initiative. In R. Lippert and S. Rehaag (eds), Sanctuary Practices in International Perspectives: Migration, Citizenship and Social Movements, pp. 162-74. Routledge.

Danish Library Act (Lov om biblioteksvirksomhed). 2000. Biblioteksstyrelsen. Köpenhamn: URL: $\underline{w w w . b s . d k / p u b l i k a t i o n e r / a n d r e / l o v / i n d e x . h t m . l ~}$

Darling, J. 2016. Defying the Demand to 'Go Home': From Human Rights Cities to the Urbanization of Human Rights. In B. Oomen, M. F. Davis, and M. Grigolo (eds), Global Urban Justice, pp. 121-38. Cambridge University Press.

Darling, J., and V. Squire. 2013. Everyday Enactments of Sanctuary. In R. Lippert and S. Rehaag (eds), Sanctuary Practices in International Perspectives: Migration, Citizenship and Social Movements, pp. 191-204. Routledge. 
De Genova, N. P. 2002. Migrant 'Illegality’ and Deportability in Everyday Life. Annual Review of Anthropology 30: 419-47.

. 2005. Working the Boundaries: Race, Space and 'Illegality' in Mexican Chicago.

Durham, NC/London: Duke University Press.

Dudley, M. 2013. The Library and the City. In M. Q. Dudley (ed.), Public Libraries and Resilient Cities, pp. 1-35. Chicago, IL: American Library Association.

Fellbom Franke, C. 2013. Urval och etik [CAN YOU PLEASE GIVE ENGLISH TRANSLATION?]. Biblioteksbladet 8: 28-30.

Graham E., P. Gready, E. Hodder, and R. Pennington. 2016. Human Rights Practice and the City: A Case Study of York. In B. Oomen, M. F. Davis, and M. Grigolo (eds), Global Urban Justice, pp. 179-98. Cambridge University Press.

Hoffman, John (2004). Citizenship Beyond the State. London: SAGE.

Holgersson, H. 2011. Icke-medborgarskapets urbana geografi. [CAN YOU PLEASE GIVE ENGLISH TRANSLATION?] Göteborg: Glänta Produktion.

Hoyer, J. 2013. Finding Room for Everyone: Libraries Confront Social Exclusion. In M. Q. Dudley (ed.), Public Libraries and Resilient Cities, pp. 57-65. Chicago, IL: American Library Association.

Hvenegaard Rasmussen, C., and H. Jochumsen. 2007. Problems and Possibilities: The Public Library in the Borderline between Modernity and Late Modernity. Library Quarterly 77(1): 45-59.

IFLA (International Federation of Library Associations and Institutions). 2016. About IFLA. http://www.ifla.org/about (referenced 8 September 2016).

International Covenant on Civil and Political Rights, 16 December 1966 (entered into force 23 March 1976).

Isin, E. F., and G. M. Nielsen (eds). 2008. Acts of Citizenship. London: Zed Books.

Justitieombudsmannen (2017) Anmälan till JO mot socialtjänsten inom samtliga stadsområdesförvaltningar i Malmö kommun samt Polismyndigheten, gränspolissektionen i region Syd [Notification to the Ombudsman against the social services in all urban area administrations in Malmö municipality and police authorities, border police section in the South region] 2017-04-20, reference number 565-2017. 
Jørgensen, M. B., and S. Meret. 2010. Irregular Migration from a Comparative Scandinavian Migration Policy Perspective. In Thomsen et al. (eds), Irregular Migration In a Scandinavian Perspective, pp. 121-52. Netherlands: Shaker Verlag. .

2012. Framing Scandinavian Conceptualizations of Irregular Migration. Nordic Journal of Migration Research 2(4): 289-97.

Khosravi, S. 2009. Sweden: Detention and Deportation of Asylum Seekers. Race \& Class 50(4): 38-56.

. 2010. An Ethnography of Migrant 'Illegality’ in Sweden: Included yet Excepted? Journal of International Political Theory 6(1): 95-116.

Laugesen, A. 2014. UNESCO and the Globalization of the Public Library Idea, 1948 to 1965. Library \& Information History 30(1): 1-19.

Lippert, R., and S. Rehaag (eds). 2013. Sanctuary Practices in International Perspectives: Migration, Citizenship and Social Movements. Routledge.

Lister, R. 2007. Inclusive Citizenship: Realizing the Potential. Citizenship Studies 11(1): 4961.

. 2009. Understanding Theories and Concepts in Social Policy. Bristol: Policy Press.

Loga, J., M. Pyykkönen, and H. Stenvaag. 2013. Holy Territories and Hospitality: Nordic Exceptionality and National Differences of Sanctuary Incidents. In R. Lippert and S. Rehaag (eds), Sanctuary Practices in International Perspectives: Migration, Citizenship and Social Movements, pp. 121-34. Routledge.

Lovén, M. 2013. Papperslösa får lånekort [CAN YOU PLEASE GIVE ENGLISH TRANSLATION?]. Sydsvenska Dagbladet. 15 June. http://www.sydsvenskan.se/2013-06-15/papperslosa-far-lanekort (referenced 9 September 2016).

Lundberg, A., and M. Strange. 2016. Who Provides the Conditions for Human Life? Sanctuary Movements in Sweden as Both Contesting and Working with State Agencies. Politics 0263395716661343.

2017. Struggles over Human Rights in Local Government: The Case of Access to Education for Undocumented Youth in Malmö, Sweden. Critical Policy Studies 11(2): 146-65.

Malmö City Library. 2013. Papperslösa får tillgång till Malmös bibliotek [CAN YOU PLEASE GIVE ENGLISH TRANSLATION?]. 
http://www.mynewsdesk.com/se/malmo/pressreleases/pappersloesa-faartillgaang-till-malmoes-bibliotek-876384 (referenced 8 September 2016).

Mancina, P. 2016. In the Spirit of Sanctuary: Sanctuary-City Policy Advocacy and the Production of Sanctuary-Power in San Francisco, California. Vanderbilt University.

Martinez, P. 2013. Engaging Communities, Making a Difference: Edmunt Library’s Community-Led Service Philosophy. In M. Q. Dudley (ed.), Public Libraries and Resilient Cities, pp. 157-63. Chicago, IL: American Library Association.

Mikkelsen, J. 2014. Papperslösa får låna böcker [CAN YOU PLEASE GIVE ENGLISH TRANSLATION?]. Sydsvenska Dagbladet. 14 March. http://www.sydsvenskan.se/2014-03-14/papperslosa-far-lana-bocker (referenced 9 September 2016)

Nordling, V. DATE. Taking Responsibility: Negotiating Undocumented Migrants’ Access to Social Rights. Doctoral dissertation, Lund University.

Nyers, P. 2008, No One Is Illegal Between City and Nation. In E. F. Isin and G. M. Nielsen (eds), Acts of Citizenship, pp. xx-xx. London: Zed Books.

Norwegian Public Library Act, LOV-1985-12-20-108, Lov om folkebibliotek.

Oldenburg, R. 1999. The Great Good Place: Cafes, Coffee Shops, Bookstores, Bars, Hair Salons, and Other Hangouts at the Heart of a Community. New York: Da Capo Press.

Oomen, B. 2016. Introduction: The Promise and Challenges of Human Rights Cities. In B. Oomen, M. F. Davis, and M. Grigolo (eds), Global Urban Justice, pp. 1-22. Cambridge University Press.

Oomen, B., M. F. Davis, and M. Grigolo (eds). 2016. Global Urban Justice: The Rise of Human Rights Cities. Cambridge University Press.

Osler, A., and H. Starkey. 2005. Changing Citizenship. McGraw-Hill Education (UK).

Oslo Battery (Batteriet). 2016. Batteriet Oslo \& Deichmann: Ny låneavtale for papirløse [CAN YOU PLEASE GIVE ENGLISH TRANSLATION?]. http://www.batteriet.no/ny-laneavtale-for-papirlose/ (referenced 9 July 2016).

Patsias, C., and N. Williams. 2013. Religious Sanctuary in France and Canada. In R. Lippert and S. Rehaag (eds), Sanctuary Practices in International Perspectives: Migration, Citizenship and Social Movements, pp. 175-88. Routledge.

Peutz , N., and N. P. De Genova (eds). 2010. The Deportation Regime: Sovereignty, Space, and the Freedom of Movement. Durham, NC: Duke University Press. 
Povrzanovic Frykman, M. 2004. Transnational Spaces: Disciplinary Perspectives. Malmö University.

Rajaram, P. K., and C. Grundy-Warr. 2004. The Irregular Migrant as Homo Sacer: Migration and Detention in Australia, Malaysia, and Thailand. International Migration 42(1): 33-64.

Rastas, A. 2013. Ethnic Identities and Transnational Subjectivities. In P. Spickard (ed.), Multiple Identities: Migrants, Ethnicity, and Membership, pp. XX-XX. Indiana University Press.

Sager, M. 2011

Sager, M., H. Holgersson, and K. Öberg. 2016. Irreguljär migration i Sverige. Rättigheter, vardagserfarenheter, motstånd och statliga kategoriseringar [CAN YOU PLEASE GIVE ENGLISH TRANSLATION?]Göteborg: Daidalos.

Schmitt, C. 1985. Political Theology: Four Chapters on the Concept of Sovereignty. University of Chicago Press.

Sigona, N. 2012. 'I Have too Much Baggage': The Impact of Legal Status on the Social Worlds of Irregular Migrants. Social Anthropology 20(1): 50-65.

Sigvardsdotter, E. 2013. Presenting Absent Bodies: Undocumented Persons Coping and Resisting in Sweden. Cultural Geographies 20(4): 523-39.

Socialstyrelsen. 2010. Social rapport 2010. Socialstyrelsen: Stockholm.

Soohoo, C. 2016. Human Rights Cities: Challenges and Possibilities. In B. Oomen, M. F. Davis, and M. Grigolo (eds), Global Urban Justice, pp. 257-75. Cambridge University Press.

Squire, V. (ed.). 2010. The Contested Politics of Mobility: Borderzones and Irregularity. New York: Routledge.

Stoltz Chinchilla N., N. Hamilton, and J. Loucky. 2009. The Sanctuary Movement and Central American Activism in Los Angeles. Latin American Perspectives 36(6): 101-26.

Swedish Library Act, SFS 2013:801, Bibliotekslag.

Swedish Local Government Act, SFS 1991:900, Kommunallag.

Swedish Proposition, 2012/13:147, Ny bibliotekslag.

UNESCO. 1994. Public Library Manifesto. http://www.unesco.org/webworld/libraries/manifestos/libraman.html (referenced 9 September 2016). 
Universal Declaration of Human Rights, adopted by UN General Assembly resolution 217A(III), 10 December 1948.

Watters, C. 2008. Refugee Children: Towards the Next Horizon. London/New York: Routledge.

Williams, L. 2006. Social Networks of Refugees in the United Kingdom: Tradition, Tactics and New Community Spaces. Journal of Ethnic and Migration Studies 32(5): 865-79.

Yukich, G. 2013a. Constructing the Model Immigrant: Movement Strategy and Immigrant Deservingness in the New Sanctuary Movement. Social Problems 60(3): 30220.

. 2013b. 'I Didn’t Know if this was Sanctuary': Strategic Adaptation in the New Sanctuary Movement. In R. Lippert and S. Rehaag (eds), Sanctuary Practices in International Perspectives: Migration, Citizenship and Social Movements, pp. 106-118. Routledge. 